IZA DP No. 5334

Whither Corruption? A Quantitative Survey of the Literature on Corruption and Growth

Nauro F. Campos

Ralitza Dimova

Ahmad Saleh

November 2010 


\title{
Whither Corruption? A Quantitative Survey of the Literature on Corruption and Growth
}

\author{
Nauro F. Campos \\ Brunel University, CEPR and IZA \\ Ralitza Dimova \\ University of Manchester and IZA
}

Ahmad Saleh

Brunel University

Discussion Paper No. 5334

November 2010

IZA

P.O. Box 7240

53072 Bonn

Germany

Phone: +49-228-3894-0

Fax: +49-228-3894-180

E-mail: iza@iza.org

Any opinions expressed here are those of the author(s) and not those of IZA. Research published in this series may include views on policy, but the institute itself takes no institutional policy positions.

The Institute for the Study of Labor (IZA) in Bonn is a local and virtual international research center and a place of communication between science, politics and business. IZA is an independent nonprofit organization supported by Deutsche Post Foundation. The center is associated with the University of Bonn and offers a stimulating research environment through its international network, workshops and conferences, data service, project support, research visits and doctoral program. IZA engages in (i) original and internationally competitive research in all fields of labor economics, (ii) development of policy concepts, and (iii) dissemination of research results and concepts to the interested public.

IZA Discussion Papers often represent preliminary work and are circulated to encourage discussion. Citation of such a paper should account for its provisional character. A revised version may be available directly from the author. 
IZA Discussion Paper No. 5334

November 2010

\section{ABSTRACT \\ Whither Corruption? A Quantitative Survey of the Literature on Corruption and Growth ${ }^{*}$}

Does corruption grease or sand the wheels of economic growth? This paper uses metaanalysis techniques to systematically evaluate the evidence addressing this question. It uses a data set comprising 460 estimates of the effect of corruption on growth from 41 empirical studies. The main factors explaining the variation in these estimates are whether the model accounts for institutions and trade openness (both are found to deflate the negative effect of corruption), authors' affiliation (academics systematically report less negative impacts), and use of fixed-effects. We also find that publication bias, albeit somewhat acute, does not eliminate the genuine negative effect of corruption on economic growth.

JEL Classification: $\quad 01$

Keywords: corruption, economic growth, meta-regression analysis

Corresponding author:

Nauro F. Campos

Department of Economics and Finance

Brunel University (West London)

Uxbridge UB8 3PH

United Kingdom

E-mail:nauro.campos@brunel.ac.uk

\footnotetext{
* We would like to thank various seminar participants at CSAE (Oxford), Royal Economic Society and Middle Eastern Economic Association conferences for comments on previous versions. The responsibility for all remaining errors is entirely ours.
} 


\section{Introduction}

Corruption happens and it happens in all countries. Although corruption is more common in poorer economies, it does exist everywhere. It is now widely accepted that corruption is not restricted to specific regions or levels of economic development (Abed and Gupta, 2002) and that the most pressing questions are which mechanisms corruption uses and how severe it actually is as a constraint on economic and political activities (Basu, 2006; Pande, 2008).

One of the defining debates in the literature on the macroeconomic consequences of corruption has been whether it greases or sands the wheels of economic growth and development. Those in favour of the greasing hypothesis argue that corruption facilitates trade that would not have happened otherwise and promotes efficiency by allowing private sector agents to circumvent cumbersome regulations (Leff, 1964; Huntington, 1968). Numerous examples support this view, showing that in highly restrictive regulatory environments, corruption can enhance economic growth by stimulating entrepreneurship and efficiency (De Soto, 1990; Egger and Winner, 2005; Levy, 2007).

Opponents of this view have constructed a solid theoretical rebuttal to these arguments by arguing that the greasing effect of corruption is only possible as a second best option in a malfunctioning institutional setting. Thus, in order to properly evaluate the effects of corruption one has to recognize its endogeneity with respect to institutions (Aidt, 2009). Theoretical analyses and empirical evidence supporting this view abound, showing that corruption sands the wheels of growth. Rock and Bonnett (2004) argue that corruption reduces investment in most developing countries and particularly in small open economies. Reinikka and Svensson (2004; 2005) find that it has detrimental effects on human capital accumulation. Concerning its magnitude, Fisman and Svensson (2001) estimate that a one percent increase in corruption leads to a three percent reduction in firm growth. This body of evidence informs the position of key international policy actors like the IMF, World Bank and 
the OECD and the ever increasing number of anti-corruption agencies and campaigns at both national and international fora (Méon and Weill, 2010).

Yet the body of empirical evidence on the economic consequences of corruption is still far from conclusive (Svensson, 2005; Aidt, 2009). For example, the literature continues to provide support to phenomena such as the so-called Asian paradox (a positive correlation between corruption and growth in a number of fairly successful Asian economies, including China) even after accounting for the crucial intermediate effect of institutions that shape the more recent versions of the greasing the wheels hypothesis (Wedeman, 2002; Rock and Bonnett, 2004; Li and Wu, 2007; Vial and Hanoteau, 2010).

The inconclusiveness of the evidence on the relationship between corruption and growth can be explained by several factors. Econometrically, regressions that attempt to infer a causal relationship between corruption and growth are often fraught with reverse causality and omitted variable problems, which have so far not found a satisfactory resolution (Aidt, 2009). In addition, the most popular measures of corruption in the empirical literature are based on expert opinions, which are often loaded with ideological bias and generate a corruption ranking of countries heavily biased towards general perceptions of current or past politico-economic performance (Razafindrakoto and Roubaud, 2010). The inconclusiveness can also be driven by publication bias: although it is understandable that not all econometric results are reported, their very selection for reporting purposes may be affected by either the preferences of journal editors or the agenda of the various international development institutions (interestingly, we find in this paper that such biases are significantly smaller in peer-reviewed publications). Finally, as well known for instance from the empirical literature on inequality and growth, cross-country correlations in the growth-related literature are generally clouded in data quality and other problems that tend to hide the welfare implications of any economic phenomena or policy (Ravallion, 2001). 
The objective of this paper is to provide a rigorous and systematic survey of the empirical literature of the effects of corruption on economic growth. ${ }^{1}$ Here we try to (1) uncover whether there is a genuine relationship between corruption and growth, (2) evaluate the direction of this relationship, and (3) identify the main factors or determinants that may help explain the variance in the observed effects of corruption on growth. For these purposes, we put together a unique data set comprising a total of 460 empirical estimates of the effect of corruption on growth from 41 different studies (listed in Appendix I). Figure 1 shows that about 32 percent of these estimates support a significant and negative impact of corruption on growth, 62 percent suggest a statistically insignificant relationship, while approximately only 6 percent support a positive and significant relation. On this account alone, one may be tempted to argue that the support for the sanding hypothesis is greater than that for the greasing hypothesis, yet note the vast majority of the results leads to arguing that the evidence is not conclusive. Why is that so? This paper uses meta-analysis and meta-regression techniques to establish the depth, extent and the reasons behind this inconclusiveness.

Our main findings refer to the identification of the main factors that explain the variation we observe in Figure 1. We find that these principal factors are authors' affiliation (academics systematically report smaller and less negative effects), the use of fixed-effects (which interestingly tend to increase the negative effect of corruption on growth), the type of corruption measure, the presence of MENA countries in the sample (which also tends to increase the overall negative effect) and the inclusion in the model of trade and institutions which both tend to deflate the negative effect of corruption on economic growth. We also find that although publication bias seems to be severe in this literature, there is plenty of evidence supporting a genuine negative effect of corruption on growth.

\footnotetext{
${ }^{1}$ There are various excellent surveys of the literature on the causes and effects of corruption, for example Bardhan (1997), Svensson (2005), Lambsdorff (2006), Pande (2008), Aidt (2003, 2009) and Treisman (2007). However ours is, to the best of our knowledge, the first quantitative survey of the econometric evidence on the corruption-growth nexus.
} 
The rest of the paper is organized as follows. In Section 2 we examine whether there is evidence for a genuine relation between corruption and growth, as well as for the existence and severity of reporting bias. In Section 3 we present the data set we constructed covering a large number of factors that can potentially explain the variation in results on this relationship available in the literature. In Section 4, we use meta-regression analysis techniques to investigate the main determinants of the variation in the corruption-growth effects. Section 5 concludes.

\section{Is there a genuine relationship between corruption and growth?}

For this paper, we put together a hand-collected data set comprising 460 estimated effects (that is, coefficients) of corruption on economic growth from 41 different empirical studies (the studies are listed in Appendix I.) The selection criteria we used are as follows. In order to be included, a paper has to investigate econometrically the relationship between corruption and economic growth across countries and it has to report regression coefficients and their tvalues or standard errors. In addition, it has to report the number of observations and/or degrees of freedom and to report sufficient information that allows us to create the explanatory variables we require (listed in Appendix II). We also include in the data set all reported regression results from each study as opposed to selecting one set of results as representative or preferred. This is because very few authors single out a set of preferred results. Notice that among the excluded studies are those that deal with only one country ("case studies") and those focusing on the effect of corruption on various macroeconomic variables other than economic growth (such as FDI, investment, inflation, government expenditures, aid and income inequality).

One explanation for the existence of bias in the literature is the alleged tendency for the evidence in academic papers to lean towards statistically significant results. The simplest 
and most often used method to detect such bias is the informal examination of a funnel graph. This is a scatter plot of the size of the treatment effect (e.g. the coefficient in a regression analysis) against a measure of its precision (Stanley, 2005; Doucouliagos and Ulubaşogilu, 2008.) Since in the absence of publication selection, estimates will vary randomly (or symmetrically) around the "true" effect, the funnel plot asymmetry is the key for identifying publication bias. ${ }^{2}$ Figure 2 shows the funnel plot for our data, which is clearly asymmetric, and thus pointing to the existence of bias. Given that visual inspections are subjective and potentially misleading, we next use meta-regression analysis to answer whether there is a genuine association between corruption and growth in a more rigorous fashion.

Stanley (2005) argues that if there is a genuine association between two variables, there should be a positive relationship between the natural logarithm of the absolute value of the t-statistic and the natural logarithm of the degrees of freedom in the regression:

$$
\ln \left|t_{i}\right|=\alpha_{0}+\alpha_{1} \ln d f_{i}+\varepsilon_{i}
$$

where $t_{i}$ and $d f_{i}$ denote the t-statistics and degrees of freedom in study $i$, respectively. Stanley $(2001 ; 2005)$ also develops a meta-significance test (MST) and shows that the value of the slope coefficient in equation [1] contains information on the extent of a publication bias and on the existence of a genuine effect. If the slope coefficient is less than zero, the evidence is said to be contaminated by publication bias and there is no genuine association between the two variables. If the slope coefficient is larger than zero, it is said that there is a genuine empirical effect. Finally, if $0<\alpha_{1}<0.5$ there is a genuine association, as well as a publication bias in the underlying body of evidence.

Given that random, large-sample misspecification biases may cause MST to identify a genuine effect too frequently, Stanley (2008) recommends complementing MST with FAT

\footnotetext{
${ }^{2}$ The intuition is that studies with a smaller sample size should have larger sampling error, while studies with a larger sample size should have lower sampling errors.
} 
(funnel asymmetry test) and PET (precision effect test). This amounts to regressing the tstatistics of the estimated effects on the inverse of their standard errors (Egger et al, 1997):

$$
t_{i}=\beta_{0}+\beta_{1} 1 / S e_{i}+u_{i}
$$

where $S e_{i}$ denotes the standard error of the estimated coefficients and $t_{i}$ denote the $\mathrm{t}-$ statistics. Testing for the statistical significance of the intercept coefficient represents a test of publication bias. This is a direct and more rigorous test of funnel plot asymmetry. Moreover, Egger et al (1997) argue that the sign of the intercept also indicates the direction of the bias. A significant slope coefficient, on the other hand, points to the existence of a genuine effect, irrespective of the possible publication bias (Stanley, 2008).

Table 1 shows the results from the FAT-PET and MST (equations 1 and 2, respectively). ${ }^{3}$ The coefficient of the degrees of freedom variable in the MST regression is statistically significant, with a value lying between zero and 0.5 , indicating that despite the presence of a publication bias, there is evidence for a genuine relationship between corruption and growth. The intercept coefficient in the FAT-PET regression is also statistically significant, thus confirming the presence of a publication bias. Moreover, the negative sign of this coefficient suggests that the bias is negative, indicating that the "true" corruption-growth relationship is less negative than that commonly reported in the literature. However, the MST estimates deliver a non significant slope coefficient in the FAT-PET regression (Table 1, columns 3 and 4) which cast doubts about the strength of a genuine effect in the corruptiongrowth literature. In order to explore this relationship further, we separate our sample in published and unpublished research and re-estimate the FAT-PET equation. Notice that out of the 41 studies in our data set, 20 are published in peer-reviewed academic journals, while 21 are working or policy papers, and reports. These results, reported in Table 2, indicate that the slope coefficient is not statistically significant only in the unpublished research sample while

\footnotetext{
${ }^{3}$ These results also obtain in a, much less standard, multivariate regression analysis (adding further study characteristics to the specification). These are available from the authors upon request.
} 
it is significant at the $1 \%$ level in the published research sample. This suggests a genuine relationship between corruption and growth in published research as well as the absence of such genuine relationship in unpublished studies. This is a very important result because it raises the possibility that unpublished studies (which may be more policy oriented) tend to tolerate, substantially more than published studies, a lenience towards a more negative and significant link between corruption and growth. Put it differently, the data shows that peerreviewed papers are systematically more likely to report a genuine yet less negative effect of corruption on growth than that of the literature as a whole. In what follows, we further investigate this issue, but first we present the full data base we put together to try to understand the variance we find in these corruption-growth effects.

\section{How does the average corruption-growth study look like?}

The preceding analysis suggests that the body of evidence exploring the relationship between corruption and economic growth may be biased and that this bias may be negative. Existing studies are systematically more likely to report negative and statistically significant estimates. We do find evidence that despite the bias, the message that the broad literature on corruption and growth conveys is genuine. If anything, there seems to be greater prejudice among peerreviewed published studies against reporting negative results than among unpublished papers and reports.

While our results are fairly instructive, a more rigorous view on the quality of the message conveyed by the existing literature on corruption and growth is needed. In keeping with the MRA literature, we attribute the potential differences in these results to either differences in the research process (e.g. differences in specification, measurement and methodology) or differences in real-world factors (e.g. regional and time differences) 
(Babetskii and Campos, 2010). The variables we construct to capture these differences are described in Appendix II, while their basic statistics are reported in Appendix III.

In order to describe the differences in econometric methodology we construct dummy variables, taking the value of 1 if the coefficients originate from a cross-sectional model $(0$ if from panel), if fixed effects are used (0 otherwise), if there is an attempt to correct for endogeneity ( 0 otherwise), if the focus of the paper is exclusively on one region ( 0 otherwise) and if the paper has been published in an academic journal ( 0 otherwise). ${ }^{4}$ Given that the approach and potential ideological bias may differ across researchers belonging to academic and non-academic environments, we also include a dummy variable that takes the value of zero if there is at least one author's affiliation is not academia.

We find that academic authors wrote 25 of the papers in our sample providing 378 estimates, thus representing $82 \%$ of the total. The regressions for only one region represent just 36 observations and $7.74 \%$ of the total. Slightly more than half of the estimates in our data set were obtained using cross sectional (54\%) while the remaining use panel data. In 151 regressions, accounting for $32.47 \%$ of the total, there is an explicit attempt to correct for endogeneity through the use of IV, 2SLS, 3SLS or GMM techniques. Moreover, fixed effects were used in 160 regressions, that is, in $34.41 \%$ of the total. About half of the estimates are reported in journal articles and the other half in working papers, $43 \%$ of these being working papers of policy oriented institutions such as World Bank and the IMF.

Measurement is an important issue, especially in light of the growing literature that questions the validity of global corruption indicators based on the perceptions of so-called experts (Razafindrakoto and Roubaud, 2010). In order to assess whether the impact of corruption on growth is significantly driven by the choice among measures of corruption, we

\footnotetext{
${ }^{4}$ One of the problems, encountered in the MRA literature is that many of the observations used in a regression analysis are not statistically independent. In meta-analysis, empirical estimates are considered statistically independent if they are reported by different authors, or if the same author reporting them uses different samples. Doucouliagos (2005) recommends the use of bootstrap to address the statistical dependence problem (reported below).
} 
construct dummy variables that take into account the differences in corruption indexes used in each study/model. The most widely used measure is from Transparency International (the Corruption Perception Index, CPI) ${ }^{5}$ which has been used in about 36 percent of the cases (or for 165 estimates). The index is available since 1995 and covers approximately 150 countries. The CPI Score is an "expert perception" measure, reflecting the degree of corruption perceived by business people and country analysts. It ranges from 10 ("highly clean") to 0 ("highly corrupt"). The second most popular measure of corruption is from the International Country Risk Guide (ICRG) of the Political Risk Group, which is used in about $28 \%$ of the regressions in our sample (130 cases). This index gives lower values for higher levels of corruption. It has monthly frequency and is available since 1984. The CTC (Control for Corruption) index of the World Bank is used in 43 cases (9.68\% of the total) and ranges from -2.5 (high corruption) to 2.5 (low corruption). ${ }^{6}$ The COMB variable captures the use of a mixture of different measures constructed by different organizations (WB, ICRG, and TI). ${ }^{7}$ It was used in 16 cases representing $3.44 \%$ of total. The CPC variable captures whether or not corruption is measured by a composite indicator, constructed by principal component analysis. The remaining measurement variable OTHER proxies measures not covered by the above categories. It was used in 94 cases accounting for $20 \%$ of our sample. ${ }^{8}$

In so far as econometric specification issues are concerned, our choice is driven by the importance of controlling for a robust set of growth determinants so that the corruption effects

\footnotetext{
5 One difficult issue is that the Transparency International index has been improved over time. In other words, there have been various changes in the underlying methodology and although these changes are vastly and carefully documented, they do generate difficulties in terms of comparing studies that use different "vintages" or "cohorts" of the CPI. We have explored this matter through interactions with a time trend and it does not qualitatively affect our main results. For more details see http://www.transparency.org/policy_research/surveys_indices/cpi

${ }^{6}$ See Kaufmann, Kraay, and Mastruzzi (2006).

${ }^{7}$ This measure is used, for instance by Rock and Bonnett (2004).

${ }^{8}$ For example, Ehrlich and Lui (1999) and Mauro (1995) use measures from Business International (BI), now incorporated into The Economist Intelligence Unit.
} 
are not unduly affected by omitted variable problems. This also allows us to investigate the relative importance of various potential channels. To this end, dummy variables were constructed taking the value of 1 if trade or trade openness is present in the model ( 0 otherwise), if institutional variables are included in the model (0 otherwise) and similarly for human capital, investment, political institutions (or democracy) and government expenditures or consumption. Trade or openness variables are included in 32 percent of the cases (i.e., in 149 regressions) while different institutional quality variables are used in 43 estimations accounting for only $9.25 \%$ of the total. Human capital or population variables are used in 337 estimations of the corruption effect, which represents $72.63 \%$ of our sample. Investment is included in 155 estimations (33.3\%) while political institutions (or democracy) are included 84 times, that is, in $18 \%$ of our sample. Government spending or consumption is included 185 times (40\% of our sample). Finally, we also create a dummy variable for whether initial conditions are included in the model specification and find that they are in 361 regressions representing $77.63 \%$ of the sample.

In order to capture the geographical focus of these corruption effects on growth, a series of dummy variables are constructed that take the value of 1 if the coefficient comes from a regression which contains transition countries ( 0 otherwise), and similarly for Latin America (LAC), Middle East (MENA), Asia (ASIA) and Sub-Saharan Africa (AFR). Note that these variables are to capture sample composition, and not whether a study is based on a single region. Transition countries were included in 401 regressions accounting for $86 \%$ of the total. Latin American countries were included 430 times representing $92.5 \%$ of the total. Middle East and North African countries were included in 401 regressions representing 86\% of the total. Asian countries were included 431 times (92.7\%) and African countries were included in 424 estimations ( $91 \%$ of the total). The variable OTHERS is used for estimations containing other country groupings (or different ways of splitting samples) such as OECD 
countries (which is used 403 times or in $86.7 \%$ of the cases). Finally, a mid- point of the time period covered by each study is calculated to try to capture time effects. ${ }^{9}$

We observe that the simple pair-wise correlation between corruption and growth, reported in the literature, is negative both in itself and across different types of methodologies, specifications, measurement choices, regions and time periods included in the underlying econometric studies. There is also a positive correlation between the length of the time window of the study and the growth-corruption relationship.

How would a typical piece of empirical research on the effect of corruption on economic growth look like using our data set? Firstly, the typical study is likely to be written by authors in academia. The time window it covers is somewhat short, with an average of nine and a half years. The typical paper does not control for endogeneity nor include country dummy variables or fixed effects. There is an almost equal chance to use panel or crosssectional data. Yet the typical paper would favour Transparency International as its main corruption measure. It is also likely to use a large multi-region sample and have human capital among its explanatory variables. Variables controlling for institutional quality are among those least likely to be found in a typical study, which is a serious omission in light of the attention this factor receives in attempts to assess the grease versus sand debate in the corruption and growth literature (Méon and Weill, 2010).

\section{What explains the variation in the estimated effect of corruption on growth?}

Many believe that the empirical literature on the effects of corruption on growth is inconclusive. Indeed Figure 1 seems to support such views: there is an awful lot of variation within the set of empirical estimates the literature has made available. Yet standard meta-

\footnotetext{
${ }^{9}$ We have also tried to deal with the difficult issue of paper quality. We collected data on the number of Google Scholar citations (excluding self-citations). It ranges from zero to 3816 (for Mauro, 1995). We used it in our empirical analysis below as the yearly average number of citations and did not find it to be a robust factor (that is, it seems that the rest of our set of explanatory variables does a good job at capturing the key elements of paper quality). These results are available upon request.
} 
analysis tests discussed above show that although the underlying relationship seems to be genuine, the available empirical evidence seems biased towards reporting negative effects of corruption on growth. This makes it even more pressing to try to pinpoint the factors that are most important in explaining the variation in the underlying corruption-growth effects. In order to do so, we estimate the following baseline equation:

$$
Y_{i}=\delta_{0}+\delta_{1} X_{i}+\varepsilon_{i}
$$

where $Y_{i}$ is the partial correlation between corruption and economic growth and $X_{i}$ is a vector of explanatory variables, which were described in section 3 above. ${ }^{10}$

In keeping with the MRA literature, we estimate both a fixed effects and a random effects version of equation [3]. The fixed effects model assumes that the heterogeneity in results is due to systematic differences across studies and to sampling error, while the random effects model assumes, in addition, that there are unobserved factors which cannot be captured by the set of explanatory variables. ${ }^{11}$ We also estimate a Weighted Least Square model (WLS), attaching greater weights to observations with higher precision. ${ }^{12}$ Finally, as indicated earlier, we use standard error bootstrapping to account for the interdependence between observations in each study (Dougouliagous, 2005). The main results from our empirical analysis are reported in Table 3 (and Table 4 provides further confirmation of these main results). Column (1) shows the fixed effects estimates, column (2) has the OLS Bootstrap estimates, the WLS estimates are reported in column (3) and the random effects (RE) estimates are in column (4). Results using the general to specific method on the WLS and RE estimators are reported in columns (5) and (6).

\footnotetext{
${ }^{10}$ For the advantages of using partial correlation as dependent variable in meta-regression analysis, see Rosenthal (1991) and Meyer and Sinani (2005).

${ }^{11}$ The tests developed in Higgins and Thompson (2002) point to the appropriateness of the randomover the fixed-effects model in this case. For sensitivity purposes, we report both models.

${ }^{12}$ See Longhi et al. (2005).
} 
Table 3 identifies that the main factors that help explain the observable variation in the corruption-growth effects are the following (in parentheses are the respective coefficients taken from Table 3, column 6): the affiliation of the authors (.14), control for endogeneity (0.07), the use of fixed-effects (-.21), the source/type of corruption measure, the presence of MENA countries in the sample (-.25), the inclusion of trade variables in the model (.16) and controlling for institutions in the econometric specification (.23). Let us now interpret these findings.

The positive and significant coefficient of the authors' affiliation variable across the different specifications indicates that non-academic authors tend to find the impact of corruption on growth to be more harmful than that found by academic authors, all else the same. This is an important result and is consistent with our finding that unpublished papers, about half of which are policy papers, tend to be more averse to report non-negative corruption-growth estimates. Also notice that although the coefficient on publication type carries the expected sign (the reported effects of corruption on growth are systematically smaller, or more negative, than those reported in peer-reviewed publications), differently from authors' affiliation, these are not robust across the different estimators

We also find that econometric models that try to control for the endogeneity of corruption with respect to economic growth tend to report more positive results than studies that do not take endogeneity into account. This suggests that the negative bias in this literature may be indeed driven by confusing correlation and causality. By contrast, studies that control for unobserved heterogeneity with the use of fixed-effects tend to report more negative effects than studies that do not account for these. Wherever significant, the signs of the measures of corruption variables are negative, which may be explained by expert perceptions being unduly driven by ideological biases (Razafindrakoto and Roubaud, 2010), translating into a larger negative reported correlation between corruption and growth. 
Possibly one of the most interesting effects meta-analysis allows one to explore is that of the "channel" variables, in this case trade or trade openness, institutional quality, human capital, investment, political/democracy effects and government consumption. The inclusion of these variables produces coefficients of corruption that measure its direct effect on growth. On the other hand, the exclusion of these variables results in the corruption variable measuring its total effect on growth. In other words, if the channel variable has a negative (positive) sign, the direct effect of corruption on growth would be smaller (larger) than the total effect (Doucouliagos and Paldam, 2006; Doucouliagos and Ulubasoglu, 2008.) The coefficients of the trade openness and institutions variables are consistently positive and significant indicating that if trade openness and institutions are positively related to growth, corruption affects these two channels negatively, thus undermining their positive growth effect. ${ }^{13}$ This latter finding provides some support for the latest versions of the grease the wheels hypothesis, whereby corruption may have a positive impact on growth predominantly in the context of malfunctioning institutions (Méon and Weill, 2010).

Finally, we examine the impact of the regional variables in our MRA analysis of the effects of corruption on growth effects. The most consistent result across specifications is that of a negative and significant impact of the MENA region on the relationship between corruption and growth and, to a somewhat lesser extent, that of a positive and significant impact of the ASIA region. This implies that corruption has a more negative impact on growth in MENA and a more positive impact on growth in ASIA. The latter result is consistent with the Asia paradox in the corruption-growth literature.

For sensitivity purposes, we re-estimate all four MRA models for each group of variables separately (Table 4). The results are mostly consistent with those in Table 3 , except

\footnotetext{
${ }^{13}$ Note that the opposite is true for the democracy variable. However, this variable is negative and significant in only two specifications. Our results for all other channels are even less conclusive.
} 
that the presence of a government expenditures variable is now significant and that the coefficients on controlling for endogeneity and the Asian variable are no longer significant.

\section{Concluding remarks}

This paper tried to provide a rigorous assessment of the relationship between corruption and economic growth, using a data set comprising 460 estimates of this effect from 41 different econometric studies. We use this unique data set to carry out an econometric survey and try to throw light on the role of differences in estimation methods, econometric specification, measurement issues, and factors like regional focus and time periods, on the distribution of overall effect of corruption on economic growth.

Maybe unsurprisingly to some, we detect a bias in the literature towards reporting negative and significant effects of corruption on growth. However, we also find evidence of a genuine effect of corruption on growth, which seems to be stronger in academic than in nonacademic studies. Further, the large degree of heterogeneity in the available corruptiongrowth results seems to be driven by whether the authors are affiliated to academic institutions and whether the underlying econometric model controls for potential endogeneity and uses fixed-effects. There seems to be support to the "sanding the wheels of growth" view of corruption, in that we do find evidence that corruption undermines the positive effect of institutions and trade openness on growth. Finally, we do find some evidence in favour of the Asian paradox (although it does not survive further sensitivity tests) and that countries in the Middle East and North Africa region are likely to experience more negative impacts of corruption on growth than countries elsewhere.

Our results have important implications for future research. Firstly, we can not find enough convincing evidence supporting the view that corruption, on its own, is capable of greasing the wheels of economic growth and development. While the "true" relationship 
between corruption and growth may be less negative than that prevailing in the literature, non-academic authors seem systematically more likely to report a negative effect than academic authors. This effect seems to go beyond whether or not the study is published in a peer-reviewed journal and, unfortunately, generates a powerful bias in this body of empirical evidence. We also conclude that the application of more rigorous econometric methodologies may be needed to sort out the debate in this literature. In particular, we would much welcome studies that combine controls for endogeneity and fixed-effects with specifications encompassing various institutional and structural reforms dimensions. If these become the norm in the future, we think that this will contribute substantially to improve our understanding of the broad economic implications of corruption. 


\section{References}

Abed, G. and Gupta, S. (eds) 2002, Governance, Corruption, and Economic Performance, International Monetary Fund, Washington, DC.

Aidt, T. 2009, "Corruption, Institutions, and Economic Development", Oxford Review of Economic Policy, vol. 25, no. 2, pp. 271-291.

Babetskii, J. and Campos, N. 2010, "Does Reform Work? An Econometric Survey of the Reform-Growth Puzzle," forthcoming Journal of Comparative Economics.

Bardhan, P. 1997, "Corruption and Development: A Review of Issues", Journal of Economic Literature, vol. 35, no. 3, pp. 1320-1346.

Basu, K. 2006, "Corruption: A Theoretical Perspective and Relevance for Economic Growth", International Review of Business Research Papers, vol. Vol.2, no. No. 4, pp. 59-68.

De Soto, H. 1990, The Other Path: The Invisible Revolution in the Third World, New York, Harper.

Doucouliagos, C. 2005, "Publication Bias in the Economic Freedom and Economic Growth Literature", Journal of Economic Surveys, vol. 19, no. 3, pp. 367-387.

Doucouliagos, H. and Paldam, M. 2006, "Aid Effectiveness on Accumulation: A Meta Study", Kyklos, vol. 59, no. 2, pp. 227-254.

Doucouliagos, H. and Ulubaşoğlu, M.A. 2008, "Democracy and Economic Growth: A MetaAnalysis", American Journal of Political Science, vol. 52, no. 1, pp. 61-83.

Egger, M., Smith, G.D., Schneider, M. and Minder, C. 1997, "Bias in Meta-analysis detected by a Simple, Graphical Test", British Medical Journal, vol. 315, no. 7109, pp. 629-634.

Egger, P. and Winner, H. 2005, "Evidence on Corruption as an Incentive for Foreign Direct Investment", European Journal of Political Economy, vol. 21, no. 4, pp. 932-952.

Ehrlich, I. and Lui, T.F. 1999, "Bureaucratic Corruption and Endogenous Economic Growth", Journal of Political Economy, vol. 107.

Fisman, R. and Svensson, J. 2007, "Are Corruption and Taxation really Harmful to Growth? Firm Level Evidence", Journal of Development Economics, vol. 83, no. 1, pp. 63-75.

Higgins, J. and S. Thompson. 2002. "Quantifying Heterogeneity in a Meta-analysis," Statistics in Medicine 21:1539-1558.

Huntington, S. 1968, Political Order in Changing Societies, New Heaven: Yale University Press.

Kaufmann, D., Kraay, A. and Mastruzzi, M. 2006, Governance Matters V: Aggregate and Individual Governance Indicators for 1996-2005, Working Paper Series 4012, World Bank. 
Lambsdorff, J. 2006, "Causes and Consequences of Corruption: What Do We Know From a Cross-Section of Countries?" in S. Rose-Ackermann (ed), International Handbook on The Economics of Corruption, Edward-Elgar, pp. 3-51.

Leff, N. 1964, "Economic Development through Bureaucratic Corruption", American Behavioral Scientist, vol. 8, no. 3, pp. 8-14.

Levy, D. 2007, "Price Adjustment under the Table: Evidence on Efficiency-enhancing Corruption", European Journal of Political Economy, vol. 23, no. 2, pp. 423-447.

Li. H., Xu, L. C. and Zou, H., 2000. "Corruption, Income Distribution, and Growth," Economics and Politics, Blackwell Publishing, vol. 12(2), pages 155-182, 07.

Li, S. and Wu, J. 2007, "Why China Thrives Despite Corruption", Far Eastern Economic Review, vol. 170, no. 3, pp. 24-28.

Longhi, S., Nijkamp, P. and Poot, J. 2005, "A Meta-Analytic Assessment of the Effect of Immigration on Wages", Journal of Economic Surveys, vol. 19, no. 3, pp. 451-477.

Mauro, P. 1995, "Corruption and Growth", The Quarterly Journal of Economics, vol. 110, no. 3, pp. 681-712.

Méon, P. and Weill, L. 2010, "Is Corruption an Efficient Grease?" World Development, vol. 38 , no. 3, pp. 244-259.

Meyer, K. and Sinani, E. 2005, "Spillovers from Foreign Direct Investment: A MetaAnalysis," Working Paper, Copenhagen Business School - Center for East European Studies.

Pande, R. 2008, "Understanding Political Corruption in Low Income Countries" in Schultz, T. and J. Strauss (Eds.) Handbook of Development Economics (Volume 4), Amsterdam: Elsevier.

Ravallion, M. 2001, "Growth, Inequality and Poverty: Looking Beyond Averages", World Development, vol. 29, no. 11, pp. 1803-1815.

Razafindrakoto, M. and Roubaud, F. 2010, "Are International Databases on Corruption Reliable? A Comparison of Expert Opinion Surveys and Household Surveys in Sub-Saharan Africa", World Development, vol. 38, no. 8, pp. 1057-1069.

Reinikka, R. and Svensson, J. 2005, "Fighting Corruption to Improve Schooling: Evidence from a Newspaper Campaign in Uganda", Journal of the European Economic Association, vol. 3 , no. 2 , pp. $259-267$.

Reinikka, R. and Svensson, J. 2004, "Local Capture", Quarterly Journal of Economics, vol. 119, no. 2, pp. 679-705.

Rock, M.T. and Bonnett, H. 2004, "The Comparative Politics of Corruption: Accounting for the East Asian Paradox in Empirical Studies of Corruption, Growth and Investment", World Development, vol. 32, no. 6, pp. 999-1017. 
Rosenthal, R. 1991, Meta Analytic Procedures for Social Research, Sage Publications, Newbury Park, California.

Stanley, T.D. 2008, "Meta-Regression Methods for Detecting and Estimating Empirical Effects in the Presence of Publication Selection", Oxford Bulletin of Economics and Statistics, vol. 70, no. 1, pp. 103-127.

Stanley, T.D. 2005, "Beyond Publication Bias", Journal of Economic Surveys, vol. 19, no. 3, pp. 309-345.

Stanley, T.D. 2001, "Wheat From Chaff: Meta-Analysis As Quantitative Literature Review", Journal of Economic Perspectives, vol. 15, no. 3, pp. 131-150.

Sterne, J.A.C. and Egger, M. 2001, "Funnel Plots for Detecting Bias in Meta-analysis: Guidelines on Choice of Axis", Journal of Clinical Epidemiology, 54(10): 1046-1055.

Svensson, J. 2005, "Eight Questions about Corruption", Journal of Economic Perspectives, vol. 19 , no. 3 , pp. 19-A3.

Treisman, D. 2007, "What Have we Learned about the Causes of Corruption from Ten Years of Cross-National Empirical Research?", Annual Review of Political Science, vol. 10, no. 1, pp. 211-244.

Vial, V. and Hanoteau, J. 2010, "Corruption, Manufacturing Plant Growth, and the Asian Paradox: Indonesian Evidence", World Development, vol. 38, no. 5, pp. 693-705.

Wedeman, A. 2002, "Development and Corruption: The East Asian paradox" in Political Business in East Asia, ed. E. Gomez, Routledge, London, pp. 34-61. 
Figure 1.

Histogram of the t-values of the coefficients of corruption on growth $(n=465)$

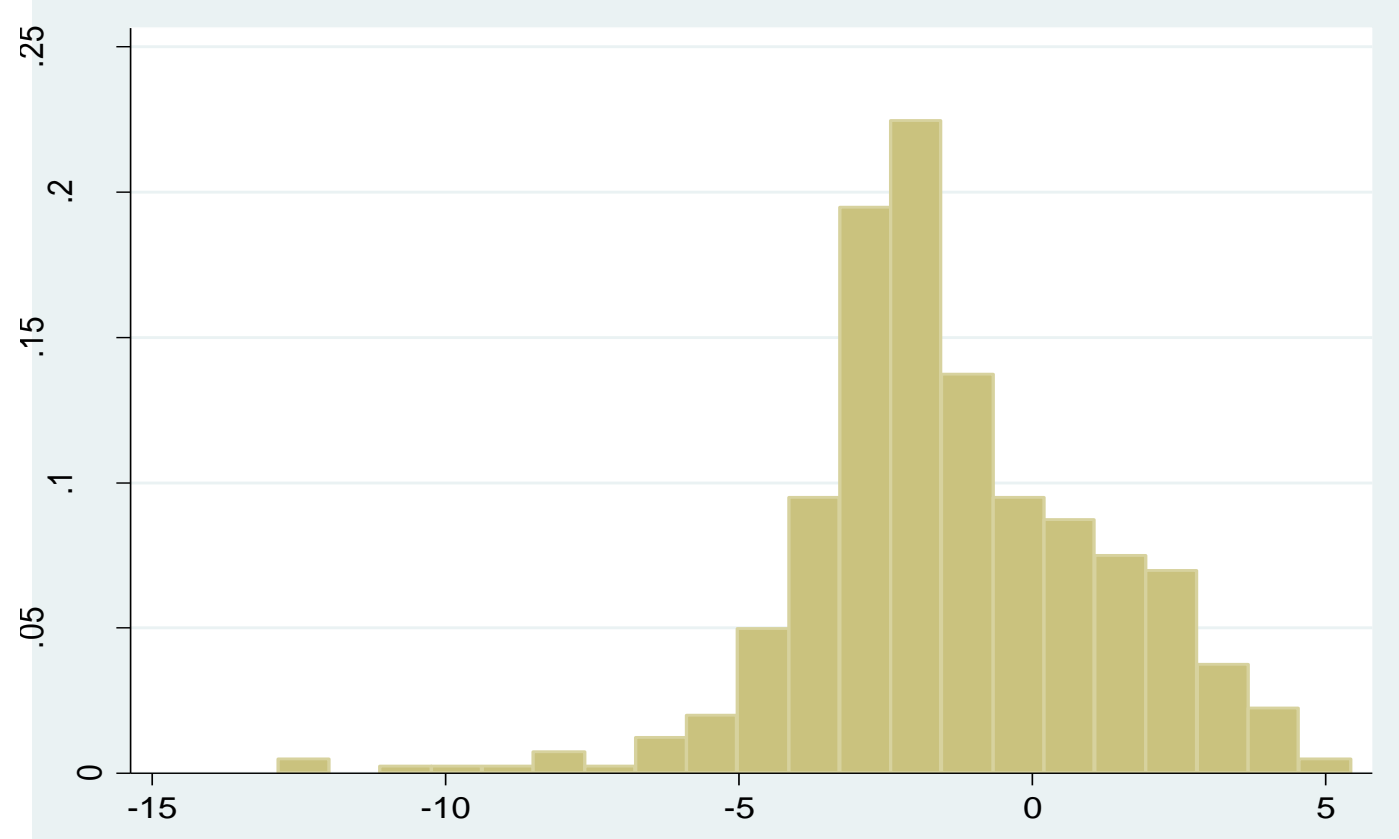

Figure 2.

Funnel plot: Estimated effect of corruption on economic growth $(n=460)$

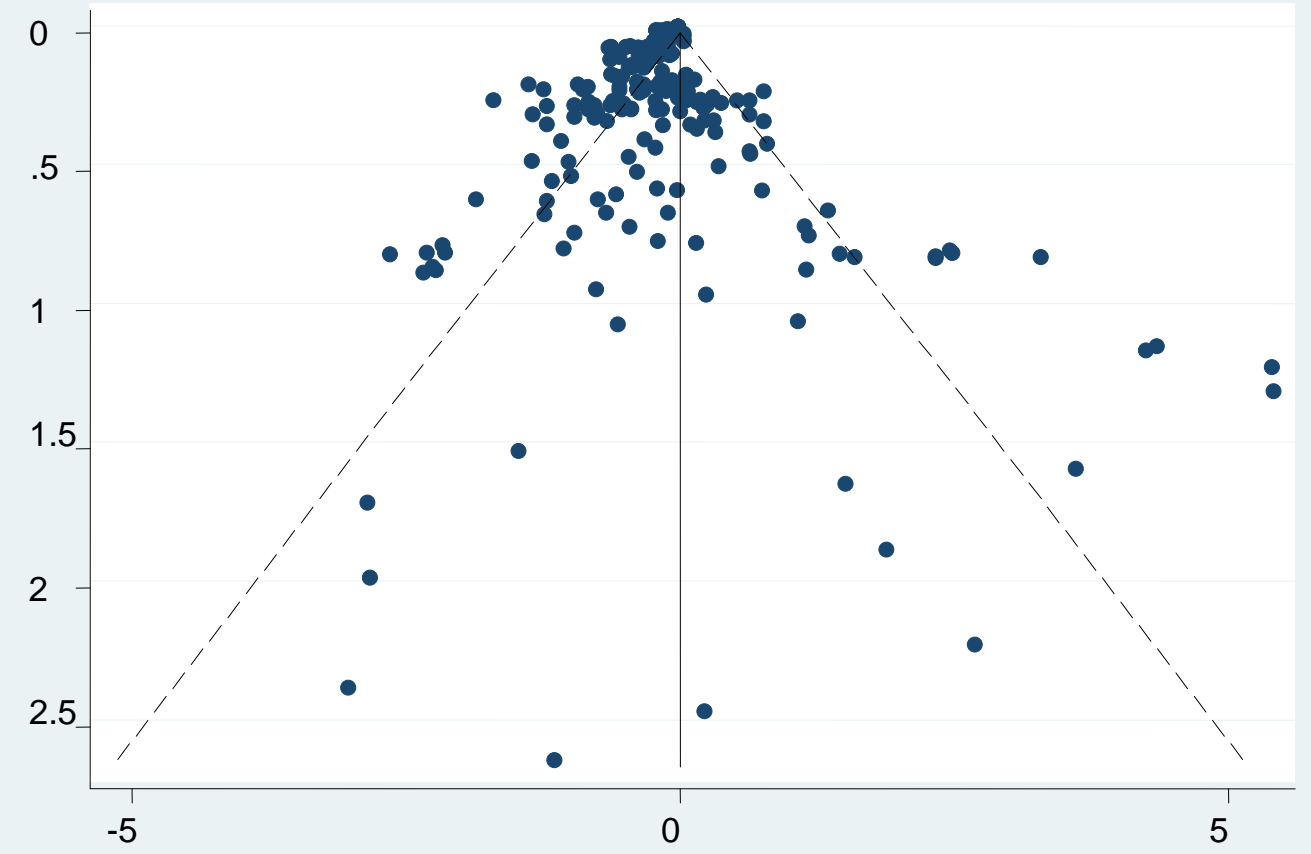


Table 1. Tests for Genuine Effect and Reporting Bias

(MST and FAT-PET tests)

\begin{tabular}{|c|c|c|c|c|}
\hline & [1] & [2] & [3] & [4] \\
\hline & $\operatorname{Ln}|\mathrm{t}|$ & $\operatorname{Ln}|t|^{\wedge}$ & $\mathrm{t}$ & $t^{\wedge}$ \\
\hline \multirow[t]{2}{*}{ Log d.f. } & 0.144 & 0.144 & & \\
\hline & $(2.54)^{*}$ & $(2.68) * *$ & & \\
\hline \multirow[t]{2}{*}{$1 / \mathrm{Se}$} & & & 0.0000463 & 0.0000463 \\
\hline & & & $(1.41)$ & $(0.11)$ \\
\hline \multirow[t]{2}{*}{ Constant } & -0.042 & -0.042 & -1.403 & -1.403 \\
\hline & $(-1.17)$ & $(-0.18)$ & $(-11.63)^{* * *}$ & $(-7.70) * * *$ \\
\hline Observations & 460 & 460 & 460 & 460 \\
\hline R-squared & 0.01 & 0.0145 & 0.21 & 0.1912 \\
\hline \multicolumn{5}{|c|}{ Absolute value of $\mathrm{t}$ statistics in parentheses } \\
\hline \multicolumn{4}{|c|}{$*$ significant at $5 \% ; * *$ significant at $1 \%$} & \\
\hline
\end{tabular}

Table 2. Tests for Genuine Effect and Reporting Bias in

Published and Unpublished Papers (MST and FAT-PET tests)

\begin{tabular}{||l|c|c|c|c||}
\hline \hline & Published & $\begin{array}{c}\text { Published, } \\
\text { Bootstrap }\end{array}$ & Unpublished & $\begin{array}{c}\text { Unpublished, } \\
\text { Bootstrap }\end{array}$ \\
\hline & {$[1]$} & {$[2]$} & {$[3]$} & {$[4]$} \\
\hline & $\mathrm{t}$ & $\mathrm{t}^{\wedge}$ & $\mathrm{t}$ & $\mathrm{t}^{\wedge}$ \\
\hline $1 / \mathrm{Se}$ & 0.000794 & 0.000720 & 0.0000172 & 0.0000219 \\
\hline & $(4.39)^{* * *}$ & $(4.48)^{* * *}$ & $(0.57)$ & $(0.73)$ \\
\hline Constant & -1.720 & -1.448 & -1.339 & -1.523 \\
\hline & $(-8.99)^{* * *}$ & $(-8.04)^{* * *}$ & $(-8.82)^{* * *}$ & $(-9.47)^{* * *}$ \\
\hline Observations & 228 & 203 & 232 & 207 \\
\hline R-squared & 0.078 & 0.091 & 0.001 & 0.003 \\
\hline Absolute value of $\mathrm{t}$ statistics in parentheses & \\
\hline$*$ significant at 5\%; $* *$ significant at 1\% & \\
\hline ^ bootstrap to derive robust standard errors with 1000 replications \\
\hline \multicolumn{5}{|l}{}
\end{tabular}


Table 3. Meta-regression analysis of the effect of corruption on economic growth

\begin{tabular}{|c|c|c|c|c|c|c|}
\hline & (1) & (2) & (3) & (4) & (5) & (6) \\
\hline VARIABLES & OLS & Bootstrap SEs & WLS & MR-RE & WLS GSpecific & MR-RE GSpecific \\
\hline \multirow[t]{2}{*}{ pubtype } & 0.0229 & 0.0229 & $-0.0845^{* *}$ & -0.0215 & $-0.0797 *$ & \\
\hline & $(0.0511)$ & $(0.0509)$ & $(0.0429)$ & $(0.0404)$ & $(0.0411)$ & \\
\hline \multirow[t]{2}{*}{ Authors } & $0.133 * *$ & $0.133 * * *$ & $0.161 * * *$ & $0.134 * * *$ & $0.160 * * *$ & $0.145 * * *$ \\
\hline & $(0.0593)$ & $(0.0405)$ & $(0.0466)$ & $(0.0453)$ & $(0.0462)$ & $(0.0390)$ \\
\hline \multirow{2}{*}{ Countryregion } & -0.104 & -0.104 & -0.0820 & -0.0118 & & \\
\hline & $(0.156)$ & $(0.137)$ & $(0.1000)$ & $(0.126)$ & & \\
\hline \multirow[t]{2}{*}{ Panel } & -0.0513 & -0.0513 & -0.0369 & -0.0468 & -0.0353 & -0.0355 \\
\hline & $(0.0477)$ & $(0.0364)$ & $(0.0341)$ & $(0.0364)$ & $(0.0342)$ & $(0.0298)$ \\
\hline \multirow[t]{2}{*}{ endo } & 0.0612 & $0.0612 * *$ & $0.0708 * *$ & $0.0685^{* *}$ & $0.0732 * *$ & $0.0703 * *$ \\
\hline & $(0.0419)$ & $(0.0305)$ & $(0.0313)$ & $(0.0318)$ & $(0.0308)$ & $(0.0290)$ \\
\hline \multirow[t]{2}{*}{ fixed } & $-0.101 * *$ & -0.101 & $-0.308 * * *$ & $-0.205^{* * *}$ & $-0.309 * * *$ & $-0.210 * * *$ \\
\hline & $(0.0491)$ & $(0.0720)$ & $(0.0464)$ & $(0.0423)$ & $(0.0461)$ & $(0.0346)$ \\
\hline \multirow[t]{2}{*}{ mid } & -0.00247 & -0.00247 & $0.00545^{* *}$ & 0.00274 & $0.00571 * *$ & 0.00274 \\
\hline & $(0.00305)$ & $(0.00352)$ & $(0.00268)$ & $(0.00251)$ & $(0.00269)$ & $(0.00244)$ \\
\hline \multirow[t]{2}{*}{$\mathrm{wb}$} & -0.0674 & -0.0674 & -0.0514 & -0.0456 & & \\
\hline & $(0.253)$ & $(0.195)$ & $(0.189)$ & (0.196) & & \\
\hline \multirow[t]{2}{*}{ icrg } & -0.229 & -0.229 & -0.242 & -0.250 & $-0.202 * *$ & $-0.106^{* * *}$ \\
\hline & $(0.242)$ & $(0.184)$ & $(0.171)$ & (0.188) & $(0.0857)$ & $(0.0356)$ \\
\hline \multirow[t]{2}{*}{ ticpi } & -0.292 & -0.292 & -0.283 & -0.266 & $-0.236 * * *$ & $-0.124 * * *$ \\
\hline & $(0.242)$ & $(0.189)$ & $(0.173)$ & $(0.188)$ & $(0.0872)$ & $(0.0348)$ \\
\hline \multirow[t]{2}{*}{ comb } & -0.333 & $-0.333^{*}$ & $-0.290 *$ & -0.327 & $-0.253 * *$ & $-0.198 * *$ \\
\hline & $(0.257)$ & (0.188) & $(0.175)$ & $(0.200)$ & $(0.110)$ & $(0.0838)$ \\
\hline \multirow[t]{2}{*}{ other } & -0.172 & -0.172 & -0.236 & -0.158 & $-0.197 * *$ & \\
\hline & $(0.242)$ & $(0.186)$ & $(0.174)$ & $(0.188)$ & $(0.0967)$ & \\
\hline \multirow[t]{2}{*}{ ctc } & -0.0178 & -0.0178 & -0.132 & -0.134 & -0.158 & \\
\hline & $(0.282)$ & $(0.230)$ & $(0.195)$ & $(0.222)$ & $(0.105)$ & \\
\hline \multirow[t]{2}{*}{ cpc } & -0.184 & -0.184 & $-0.219^{*}$ & $-0.195 * *$ & $-0.209^{*}$ & $-0.206^{* *}$ \\
\hline & $(0.123)$ & (0.114) & $(0.132)$ & $(0.0935)$ & $(0.124)$ & $(0.0855)$ \\
\hline \multirow[t]{2}{*}{ initcond } & -0.0443 & -0.0443 & $-0.138 * * *$ & $-0.0926^{*}$ & $-0.137 * * *$ & $-0.0869 *$ \\
\hline & $(0.0650)$ & $(0.0589)$ & $(0.0501)$ & $(0.0504)$ & $(0.0492)$ & $(0.0454)$ \\
\hline
\end{tabular}




\begin{tabular}{|c|c|c|c|c|c|c|}
\hline transit & $\begin{array}{c}0.0542 \\
(0.0814)\end{array}$ & $\begin{array}{c}0.0542 \\
(0.0746)\end{array}$ & $\begin{array}{c}-0.102 \\
(0.0653)\end{array}$ & $\begin{array}{c}-0.00532 \\
(0.0627)\end{array}$ & $\begin{array}{l}-0.113^{*} \\
(0.0626)\end{array}$ & \\
\hline asia & $\begin{array}{c}0.286 \\
(0.353)\end{array}$ & $\begin{array}{c}0.286^{* *} \\
(0.124)\end{array}$ & $\begin{array}{c}0.391 * * * \\
(0.129)\end{array}$ & $\begin{array}{l}0.328 \\
(0.315)\end{array}$ & $\begin{array}{c}0.498 * * * \\
(0.170)\end{array}$ & $\begin{array}{c}0.363^{* * *} \\
(0.103)\end{array}$ \\
\hline afr & $\begin{array}{l}0.0840 \\
(0.120)\end{array}$ & $\begin{array}{l}0.0840 \\
(0.114)\end{array}$ & $\begin{array}{c}0.232^{* *} \\
(0.104)\end{array}$ & $\begin{array}{c}0.172 * \\
(0.0939)\end{array}$ & $\begin{array}{c}0.229 * * \\
(0.104)\end{array}$ & $\begin{array}{c}0.164^{*} \\
(0.0879)\end{array}$ \\
\hline trade & $\begin{array}{l}0.129 * * \\
(0.0526)\end{array}$ & $\begin{array}{c}0.129 * * * \\
(0.0434)\end{array}$ & $\begin{array}{c}0.198 * * * \\
(0.0353)\end{array}$ & $\begin{array}{c}0.158 * * * \\
(0.0398)\end{array}$ & $\begin{array}{c}0.198 * * * \\
(0.0349)\end{array}$ & $\begin{array}{c}0.161 * * * \\
(0.0371)\end{array}$ \\
\hline instit & $\begin{array}{c}0.219 * * * \\
(0.0816)\end{array}$ & $\begin{array}{c}0.219 * * * \\
(0.0563)\end{array}$ & $\begin{array}{c}0.223 * * * \\
(0.0538)\end{array}$ & $\begin{array}{c}0.220 * * * \\
(0.0620)\end{array}$ & $\begin{array}{c}0.237 * * * \\
(0.0497)\end{array}$ & $\begin{array}{c}0.235^{* * * *} \\
(0.0550)\end{array}$ \\
\hline political & $\begin{array}{l}-0.0855 \\
(0.0594)\end{array}$ & $\begin{array}{l}-0.0855 \\
(0.0662)\end{array}$ & $\begin{array}{l}-0.0983^{*} \\
(0.0581)\end{array}$ & $\begin{array}{l}-0.0742 \\
(0.0462)\end{array}$ & $\begin{array}{l}-0.0907 \\
(0.0572)\end{array}$ & $\begin{array}{c}-0.0905 * * \\
(0.0416)\end{array}$ \\
\hline gov & $\begin{array}{l}-0.0706 \\
(0.0493)\end{array}$ & $\begin{array}{l}-0.0706 \\
(0.0549)\end{array}$ & $\begin{array}{l}-0.0361 \\
(0.0431)\end{array}$ & $\begin{array}{l}-0.0412 \\
(0.0387)\end{array}$ & $\begin{array}{l}-0.0399 \\
(0.0405)\end{array}$ & $\begin{array}{l}-0.0406 \\
(0.0363)\end{array}$ \\
\hline Constant & $\begin{array}{l}-0.0837 \\
(0.271)\end{array}$ & $\begin{array}{l}-0.0837 \\
(0.207)\end{array}$ & $\begin{array}{c}-0.0236 \\
(0.207)\end{array}$ & $\begin{array}{c}-0.0696 \\
(0.210)\end{array}$ & $\begin{array}{l}-0.0545 \\
(0.142)\end{array}$ & $\begin{array}{c}-0.226 * * * \\
(0.0839)\end{array}$ \\
\hline $\begin{array}{l}\text { Observations } \\
\text { R-squared }\end{array}$ & $\begin{array}{c}460 \\
0.185\end{array}$ & $\begin{array}{c}460 \\
0.185\end{array}$ & $\begin{array}{c}438 \\
0.448\end{array}$ & 460 & $\begin{array}{c}438 \\
0.447\end{array}$ & 460 \\
\hline
\end{tabular}

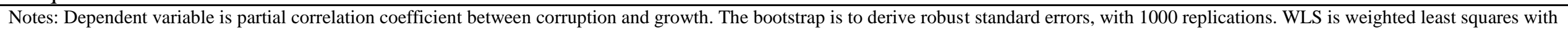

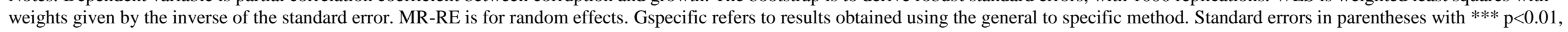
$* * \mathrm{p}<0.05, * \mathrm{p}<0.1$. All estimations carried out through the metareg routine in STATA. 
Table 4. Meta-regression analysis the effect of corruption on economic growth: Sensitivity analysis

\begin{tabular}{|c|c|c|c|c|c|c|c|c|c|c|c|c|}
\hline VARIABLES & $\begin{array}{c}(1) \\
\text { OLS }\end{array}$ & $\begin{array}{c}(2) \\
\text { Bootstrap } \\
\text { SEs } \\
\end{array}$ & $\begin{array}{c}(3) \\
\text { WLS }\end{array}$ & $\begin{array}{c}\text { (4) } \\
\text { MR-RE }\end{array}$ & $\begin{array}{c}(5) \\
\text { OLS }\end{array}$ & $\begin{array}{c}(6) \\
\text { bootstrap }\end{array}$ & $\begin{array}{c}(7) \\
\text { WLS }\end{array}$ & $\begin{array}{c}(8) \\
\text { MR-RE }\end{array}$ & $\begin{array}{c}(9) \\
\text { OLS }\end{array}$ & $\begin{array}{c}(10) \\
\text { bootstrap }\end{array}$ & $\begin{array}{c}(11) \\
\text { WLS }\end{array}$ & $\begin{array}{c}\text { (12) } \\
\text { MR-RE }\end{array}$ \\
\hline pubtype & $\begin{array}{l}0.00192 \\
(0.0405)\end{array}$ & $\begin{array}{l}0.00192 \\
(0.0361)\end{array}$ & $\begin{array}{c}-0.0821 * * \\
(0.0387)\end{array}$ & $\begin{array}{l}-0.0247 \\
(0.0324)\end{array}$ & & & & & & & & \\
\hline authors & $\begin{array}{c}0.208 * * * \\
(0.0470)\end{array}$ & $\begin{array}{c}0.208 * * * \\
(0.0321)\end{array}$ & $\begin{array}{c}0.196 * * * \\
(0.0359)\end{array}$ & $\begin{array}{c}0.197 * * * \\
(0.0369)\end{array}$ & & & & & & & & \\
\hline countryregion & $\begin{array}{c}0.0496 \\
(0.0751)\end{array}$ & $\begin{array}{c}0.0496 \\
(0.0542)\end{array}$ & $\begin{array}{c}0.0441 \\
(0.0567)\end{array}$ & $\begin{array}{c}0.0540 \\
(0.0591)\end{array}$ & & & & & & & & \\
\hline panel & $\begin{array}{c}0.0262 \\
(0.0360)\end{array}$ & $\begin{array}{c}0.0262 \\
(0.0315)\end{array}$ & $\begin{array}{l}0.0626 * \\
(0.0332)\end{array}$ & $\begin{array}{c}0.0430 \\
(0.0286)\end{array}$ & & & & & & & & \\
\hline endo & $\begin{array}{c}-0.000778 \\
(0.0388)\end{array}$ & $\begin{array}{c}-0.000778 \\
(0.0298)\end{array}$ & $\begin{array}{c}0.0382 \\
(0.0311)\end{array}$ & $\begin{array}{c}0.0171 \\
(0.0306)\end{array}$ & & & & & & & & \\
\hline fixed & $\begin{array}{c}-0.150 * * * \\
(0.0381)\end{array}$ & $\begin{array}{c}-0.150 * * * \\
(0.0468)\end{array}$ & $\begin{array}{c}-0.318 * * * \\
(0.0496)\end{array}$ & $\begin{array}{c}-0.206^{* * * *} \\
(0.0318)\end{array}$ & & & & & & & & \\
\hline mid & $\begin{array}{l}-0.00147 \\
(0.00279)\end{array}$ & $\begin{array}{l}-0.00147 \\
(0.00271)\end{array}$ & $\begin{array}{l}0.00564 * \\
(0.00317)\end{array}$ & $\begin{array}{c}0.00107 \\
(0.00221)\end{array}$ & & & & & & & & \\
\hline $\mathrm{wb}$ & & & & & $\begin{array}{c}0.00755 \\
(0.259)\end{array}$ & $\begin{array}{c}0.00755 \\
(0.196)\end{array}$ & $\begin{array}{l}0.0362 \\
(0.185)\end{array}$ & $\begin{array}{l}0.0167 \\
(0.210)\end{array}$ & & & & \\
\hline icrg & & & & & $\begin{array}{c}-0.260 \\
(0.243)\end{array}$ & $\begin{array}{c}-0.260 \\
(0.180)\end{array}$ & $\begin{array}{c}-0.319 * * \\
(0.161)\end{array}$ & $\begin{array}{l}-0.310 \\
(0.198)\end{array}$ & & & & \\
\hline ticpi & & & & & $\begin{array}{l}-0.313 \\
(0.243)\end{array}$ & $\begin{array}{c}-0.313 * \\
(0.175)\end{array}$ & $\begin{array}{c}-0.379 * * \\
(0.161)\end{array}$ & $\begin{array}{c}-0.330 * \\
(0.197)\end{array}$ & & & & \\
\hline comb & & & & & $\begin{array}{c}-0.554 * * \\
(0.256)\end{array}$ & $\begin{array}{c}-0.554 * * * \\
(0.175)\end{array}$ & $\begin{array}{c}-0.595 * * * \\
(0.161)\end{array}$ & $\begin{array}{c}-0.568 * * * \\
(0.208)\end{array}$ & & & & \\
\hline other & & & & & $\begin{array}{l}-0.225 \\
(0.244)\end{array}$ & $\begin{array}{c}-0.225 \\
(0.179)\end{array}$ & $\begin{array}{c}-0.471 * * * \\
(0.180)\end{array}$ & $\begin{array}{l}-0.249 \\
(0.198)\end{array}$ & & & & \\
\hline ctc & & & & & $\begin{array}{l}-0.0640 \\
(0.247)\end{array}$ & $\begin{array}{c}-0.0640 \\
(0.178)\end{array}$ & $\begin{array}{l}-0.109 \\
(0.163)\end{array}$ & $\begin{array}{c}-0.0946 \\
(0.200)\end{array}$ & & & & \\
\hline срс & & & & & $\begin{array}{l}-0.0347 \\
(0.0943)\end{array}$ & $\begin{array}{l}-0.0347 \\
(0.0977)\end{array}$ & $\begin{array}{l}0.0893 \\
(0.143)\end{array}$ & $\begin{array}{c}-0.00380 \\
(0.0742)\end{array}$ & & & & \\
\hline
\end{tabular}


initcond

transit

lac

mena

asia

afr

others

trade

instit

human

invest

political

gov

Constant

$$
\begin{array}{cc}
-0.265 * * * & -0.265 * * * \\
(0.0593) & (0.0381)
\end{array}
$$

460

0.071

438
0.264

R-squared

$-0.284 * * * \quad 0.114$

$-0.284 * * *$
$(0.0461)$

0.114
$(0.241)$

460

460
0.082

0.114

(0.173)

(0.160)

Notes: Depend

weights given by the

routine in STATA. 


\section{Appendix I}

\section{Econometric studies of the effect of corruption on economic growth}

1. Abdiweli, M., 2006. "Institutional differences as sources of growth differences," Atlantic Economic Journal 31(4): 348-362, December.

2. Abed, T. and Davoodi, R., 2000. "Corruption, Structural Reforms, and Economic Performance in the Transition Economies," IMF, Washington DC, IMF Working Paper No. $00 / 132$

3. Ahlin, C. and Pang, J., 2007. "Are Financial Development and Corruption Control Substitutes in Promoting Growth," Vanderbilt University, Department of Economics, Working Paper No. 07-W09, May.

4. Aidt, T., Dutta, J. And V. Sena, 2005. "Growth, Governance and Corruption in the Presence of Threshold Effects Theory and Evidence," Cambridge University, Working Papers in Economics 0540, September.

5. Anoruo, E. and Braha, H., 2005. "Corruption and Economic Growth: The African Experience." Mimeo.

6. Åslund, A. and Jenish, N., 2006. "The Eurasian Growth Paradox," the Institute for International Economics, Washington DC, Working Paper No. 06-5, June.

7. Barro, B., 1996."Determinants of Economic Growth: A Cross-Country Empirical Study," NBER Working Papers 5698, National Bureau of Economic Research, Inc.

8. Brunnetti, A., Kisunko, G., and Weder, B., 1997. "Credibility of rules and economic growth: evidence from a worldwide survey of the private sector," Policy Research Working Paper Series 1760, The World Bank.

9. Butkiewicz, J. L., and Yanikkaya, H., 2006. "Institutional quality and economic growth: Maintenance of the rule of law or democratic institutions, or both?," Economic Modelling, Elsevier, vol. 23(4), pages 648-661, July.

10. Dreher, A. and Herzfeld, T., 2005."The Economic Costs of Corruption: A Survey and New Evidence," Public Economics 0506001, Econ WPA.

11. Drury, A.C., Krieckhaus, J. and Lusztig, M., 2006. Corruption, Democracy, and Economic Growth. International Political Science Review/ Revue internationale de science politique, 27(2), pp. 121-136.

12. Edison, H.J., Levine, R., Ricci, L. and Sløk, T., 2002. International financial integration and economic growth. Journal of International Money and Finance, 21(6), pp. 749-776.

13. Ehrlich, I. and Lui, F.T., 1999. Bureaucratic Corruption and Endogenous Economic Growth. The Journal of Political Economy, 107(6, Part 2: Symposium on the Economic Analysis of Social Behavior in Honor of Gary S. Becker), pp. S270-S293. 
14. Fitzsimons, G.V., 2003. "The Hidden Economy and the Growth of Corruption in Transition Economies: causes and consequences." Athenian Policy Forum (APF) Cambridge conference, Homerton College Cambridge, August.

15. Gyimah-Brempong, K., 2002."Corruption, economic growth, and income inequality in Africa," Economics of Governance, Springer, vol. 3(3), pages 183-209, November.

16. Gyimah-Brempong, K. And Gyimah-Brempong, S., 2006. "Corruption, Growth, and Income Distribution: Are there Regional Differences?," Economics of Governance, Springer, vol. 7(3), pages 245-269, August.

17. Gupta, S., Davoodi, H. and Alonso-Terme, R., 2002. "Does corruption affect income inequality and poverty?," Economics of Governance, Springer, vol. 3(1), pages 23-45, 03.

18. Haile, D. and Abdolkarim Sadrieh, A. and Verbon, H. A. A., 2003. "Self-Serving Dictators and Economic Growth," CESifo Working Paper Series CESifo Working Paper No.1105, December.

19. Hakura, D., 2004."Growth in the Middle East and North Africa," IMF Working Papers 04/56, International Monetary Fund, April.

20. Isham, J., Woolcock, M., Pritchett, L. and Busby, G., 2005. "The Varieties of Resource Experience: Natural Resource Export Structures and the Political Economy of Economic Growth.” The World Bank Economic Review, 19 (2), pp. 141-174.

21. Jayasuriya, R. and Wodon, Q., 2005. "Measuring and Explaining the Impact of Productive Efficiency on Economic Development." The World Bank Economic Review, 19 (1), pp. 121 140.

22. Knack, S., 2006. "Governance and Growth,” Mimeo, October.

23. Li. H., Xu, L. C. and Zou, H., 2000. "Corruption, Income Distribution, and Growth," Economics and Politics, Blackwell Publishing, vol. 12(2), pages 155-182, 07.

24. Mamoon, D. and Murshed, S.M., 2005. "Are institutions more important than integration?," Working Papers - General Series 416, Institute of Social Studies.

25. Matthew A. Cole, 2007. "Corruption, income and the environment: An empirical analysis," Ecological Economics 62, (3-4): 637-647, May.

26. Mauro, P., 1995. "Corruption and Growth," The Quarterly Journal of Economics, MIT Press, vol. 110(3), pages 681-712, August.

27. Mauro, P., 1996. "The Effects of Corruption on Growth, Investment, and Government Expenditure," IMF Working Papers 96/98, International Monetary Fund.

28. Mendez, F. and Sepulveda, F., 2006. "Corruption, growth and political regimes: Cross country evidence," European Journal of Political Economy, Elsevier, vol. 22(1), pages 8298, March.

29. Méon, P. and Sekkat, K., 2005. "Does corruption grease or sand the wheels of growth?," Public Choice, Springer, vol. 122(1), pages 69-97, January. 
30. Mironov, M., 2005. "Bad Corruption, Good Corruption and Growth" University of Chicago, Graduate School of Business, November.

31. Mo, P.H., 2001. "Corruption and Economic Growth," Journal of Comparative Economics, 29(1), pp. 66-79.

32. Neeman, Z., Paserman, D. and Simhon, A., 2003. "Corruption and Openness," CEPR Discussion Papers 4057, C.E.P.R. Discussion Papers.

33. Papyrakis, E. and Gerlagh, R., 2004. "The resource curse hypothesis and its transmission channels," Journal of Comparative Economics, Elsevier, vol. 32(1), pages 181-193, March.

34. Pellegrini, L. and Gerlagh, R., 2004. "Corruption's Effect on Growth and its Transmission Channels," Kyklos, Blackwell Publishing, vol. 57(3), pages 429-456, 08.

35. Poirson, H., 1998. "Economic Security, Private Investment, and Growth in Developing Countries," IMF Working Papers 98/4, International Monetary Fund.*

36. Rahman, A., Kisunko, G. and Kapoor, K., 2000."Estimating the effects of corruption implications for Bangladesh," Policy Research Working Paper Series 2479, The World Bank.

37. Rock, M.T. and Bonnett, H., 2004. "The Comparative Politics of Corruption: Accounting for the East Asian Paradox in Empirical Studies of Corruption, Growth and Investment," World Development, Elsevier, vol. 32(6), pages 999-1017, June.

38. Shaw, P., Katsaiti, M. and Jurgilas, M., 2006. "Corruption and Growth Under Weak Identification," Working papers 2006-17, University of Connecticut, Department of Economics, revised Mar 2007.

39. Tanzi, V. and Davoodi, H.R., 2000. "Corruption, Growth, and Public Finances," IMF Working Papers 00/182, International Monetary Fund.

40. Toatu, T., 2004. "Corruption, Public Investment and Economic Growth: Evidence from Pacific Island Countries," University of the South Pacific, Suva, Fiji, PIAS-DG Governance Program Working Paper, October.

41. Welsch, H., 2004. "Corruption, growth, and the environment: a cross-country analysis," Environment and Development Economics, Cambridge University Press, vol. 9(05), pages 663-693, October. 
Appendix II Variable definitions

\begin{tabular}{|c|c|}
\hline VARIABLE NAME & DEFINITION \\
\hline authors & Dummy, if all authors from academia=1. \\
\hline panel & Dummy, if the model use cross sectional data $=1$. \\
\hline endo & Dummy, if the model control for endogeneity $=1$. \\
\hline fixed & Dummy, if the model accounts for fixed effects or country dummy $=1$. \\
\hline pubtype & Dummy, if the study is published in refereed journal $=1$. \\
\hline $\mathrm{wb}$ & Dummy, if model uses World Bank corruption measure $=1$. \\
\hline icrg & $\begin{array}{l}\text { Dummy, if model uses International Country Risk Guide measure of corruption } \\
=1 \text {. }\end{array}$ \\
\hline ticpi & Dummy, if model uses Transparency International measure $=1$. \\
\hline comb & Dummy, if model uses combined corruption measure (WB, ICRG, TI) =1. \\
\hline other & Dummy, if model uses other corruption measures $=1$. \\
\hline ctc. & Dummy, if model uses Control to Corruption measure $=1$. \\
\hline срс & $\begin{array}{l}\text { Dummy, if model uses corruption measure constructed by principal } \\
\text { components }==1\end{array}$ \\
\hline trade & Dummy, if model contains trade or openness variable $=1$. \\
\hline instit & Dummy, if model contains institutional variable $=1$. \\
\hline human & Dummy, if model contains human capital or population variable $=1$. \\
\hline invest & Dummy, if model contains investment variable $=1$. \\
\hline political & Dummy, if model contains political or democracy variable $=1$. \\
\hline gov & $\begin{array}{l}\text { Dummy, if model contains government expenditures variable }=1 . \\
.\end{array}$ \\
\hline transit & Dummy, if the study contains transition countries $=1$. \\
\hline lac & Dummy, if the study contains Latin American countries $=1$. \\
\hline mena & Dummy, if the study contains Middle East and North Africa countries=1. \\
\hline asia & Dummy, if the study contains Asian countries $=1$. \\
\hline afr & Dummy, if the study contains African countries $=1$. \\
\hline others & Dummy, if the study contains other countries not specified above $=1$. \\
\hline initcond & Dummy, if initial conditions included in the regression $=1$. \\
\hline
\end{tabular}


Appendix III Descriptive statistics

\begin{tabular}{||l|c|c|c|c|c|c|c||}
\hline \hline & Obs. & Mean & St. dev. & Min. & Max. & Freq. & Percent \\
\hline df & 460 & 101.37 & 173.06 & 0 & 1498 & - & - \\
\hline authors & 460 & 0.82 & 0.38 & 0 & 1 & 378 & 82.00 \\
\hline countryregion & 460 & 0.07 & 0.26 & 0 & 1 & 36 & 7.74 \\
\hline panel & 460 & 0.53 & 0.50 & 0 & 1 & 249 & 53.55 \\
\hline endo & 460 & 0.33 & 0.47 & 0 & 1 & 151 & 32.47 \\
\hline fixed & 460 & 0.35 & 0.48 & 0 & 1 & 160 & 34.41 \\
\hline mid & 460 & 9.54 & 6.21 & 0 & 20 & - & - \\
\hline pubtype & 460 & 0.50 & 0.50 & 0 & 1 & 228 & 49.03 \\
\hline wb & 460 & 0.03 & 0.17 & 0 & 1 & 13 & 2.8 \\
\hline icrg & 460 & 0.28 & 0.45 & 0 & 1 & 130 & 27.96 \\
\hline ticpi & 460 & 0.36 & 0.48 & 0 & 1 & 165 & 35.48 \\
\hline comb & 460 & 0.03 & 0.18 & 0 & 1 & 16 & 3.44 \\
\hline other & 460 & 0.20 & 0.40 & 0 & 1 & 94 & 20.22 \\
\hline ctc. & 460 & 0.09 & 0.29 & 0 & 1 & 45 & 9.68 \\
\hline cpc & 460 & 0.03 & 0.17 & 0 & 1 & 14 & 3.01 \\
\hline trade & 460 & 0.32 & 0.47 & 0 & 1 & 149 & 32.04 \\
\hline instit & 460 & 0.09 & 0.29 & 0 & 1 & 43 & 9.25 \\
\hline human & 460 & 0.73 & 0.45 & 0 & 1 & 337 & 72.63 \\
\hline invest & 460 & 0.33 & 0.47 & 0 & 1 & 155 & 33.33 \\
\hline political & 460 & 0.18 & 0.39 & 0 & 1 & 84 & 18.06 \\
\hline gov & 460 & 0.40 & 0.49 & 0 & 1 & 185 & 39.78 \\
\hline transit & 460 & 0.86 & 0.34 & 0 & 1 & 401 & 86.24 \\
\hline lac & 460 & 0.93 & 0.26 & 0 & 1 & 430 & 92.47 \\
\hline mena & 460 & 0.86 & 0.34 & 0 & 1 & 401 & 86.24 \\
\hline asia & 460 & 0.93 & 0.26 & 0 & 1 & 431 & 92.69 \\
\hline afr & 460 & 0.91 & 0.28 & 0 & 1 & 424 & 91.18 \\
\hline others & 460 & 0.87 & 0.34 & 0 & 1 & 403 & 86.67 \\
\hline initcond & 460 & 0.78 & 0.41 & 0 & 1 & 361 & 77.63 \\
\hline \hline & & & & & & & \\
\hline
\end{tabular}

